
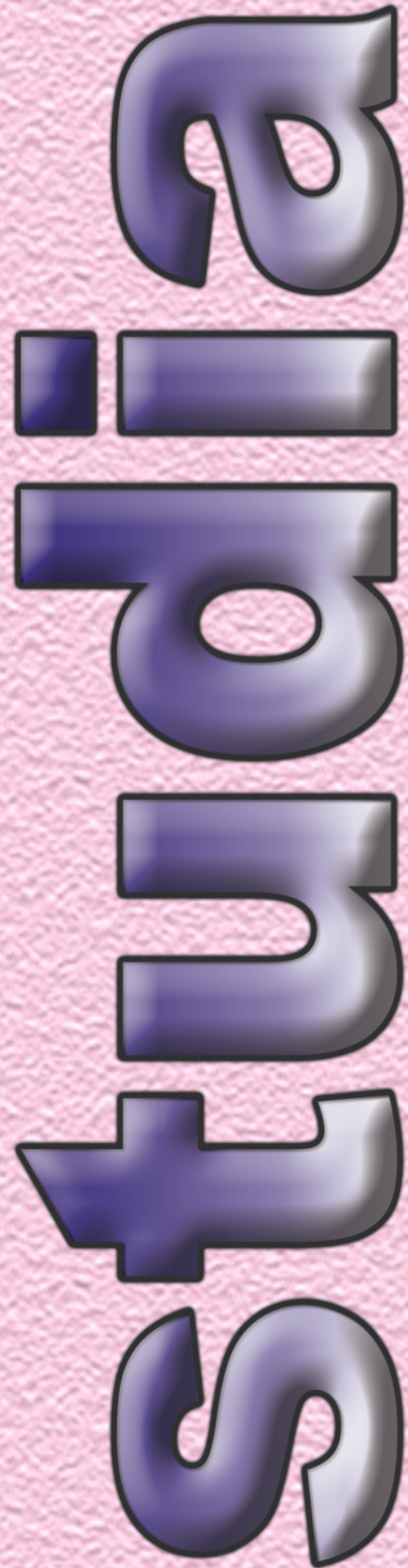

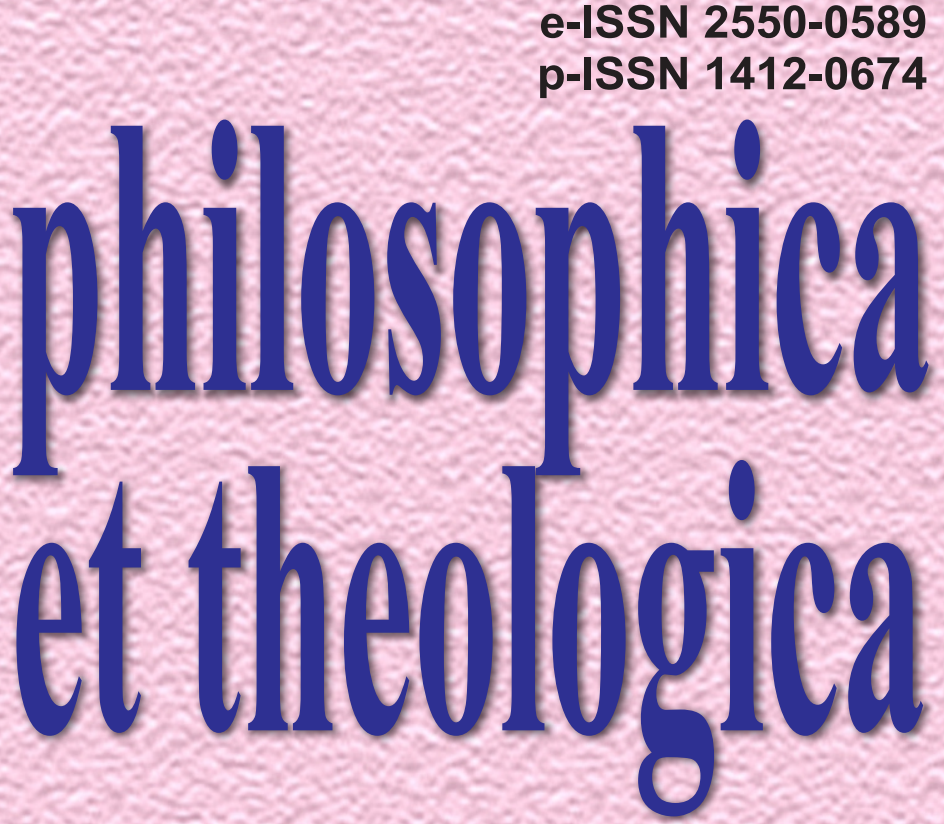

Pandemi Covid 19 dalam Perspektif Visi Kebangkitan Paus Fransiskus

Martinus Dam Febrianto

Formasi Berkelanjutan:

Membermaknakan Kekinian Imamat Edison R.L. Tinambunan

Imajinasi untuk Merawat Kemanusiaan: Pemikiran Martha Nussbaum dalam Pendidikan Humaniora Cicilia Damayanti

Diskursus Hukum Kodrat dan Problem Pascamodernitas Hizkia Fredo Valerian

Polemik Antara Original Event dan Original Purpose dalam Liturgi: Spiritualita Liturgi Ekaristi dalam Perspektif Sejarah Liturgi dan Kitab Suci Robert Pius Manik

Piet Go, Ensiklik Rerum Novarum dan Quadragesimo Anno dan Transformasi Moral Millenial Godlif Sianipar

Applying Bardach and patashnik's Poliy Concept to Educational Leadership Development Effort in the Developing World Gregorius Kukuh Nugroho *****

TELAAH BUKU 


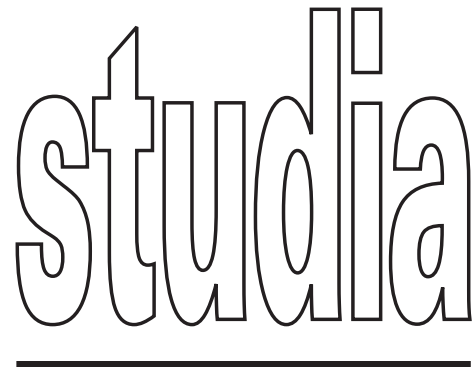

STUDIA PHILOSOPHICA ET THEOLOGICA (ISSN Print 1412-0674 and ISSN Online 2550-0589) is a bilingual (Indonesian and English language) and peer reviewed journal published by Center of Research of Widya Sasana School of Philosophy Theology, Malang. STUDIA specializes in researched papers related to contextualization and inculturation of theology and philosophy from inter-disciplinary-methodological point of view. Journal has 2 issues per year (April and October)

STUDIA welcomes philosophical and theological contributions from scholars with various background of disciplines. This journal uses English and Indonesian Language. STUDIA is an open access journal whose papers published is freely downloaded.

\section{FOCUS AND SCOPE:}

STUDIA focuses on philosophical and theological studies based on both literary and field researches. The emphasis of study is on systematic attempt of exploring seeds of Indonesian philosophy as well as contextualization and inculturationof theology in socio-political-historical atmosphere of Indonesia.

Scope of STUDIA covers various perspectives of philosophical and theological studies from interdisciplinary methodology and cultural-religious point of view of traditions.

\section{PUBLISHER :}

P3M Sekolah Tinggi Filsafat Teologi

Widya Sasana Malang

Jl. Terusan Rajabasa 2,

Malang 65146 Indonesia

Telp. 0341 - 552120

Fax. 0341 - 566676

Email : stftws@gmail.com

Website : ejournal.stftws.ac.id

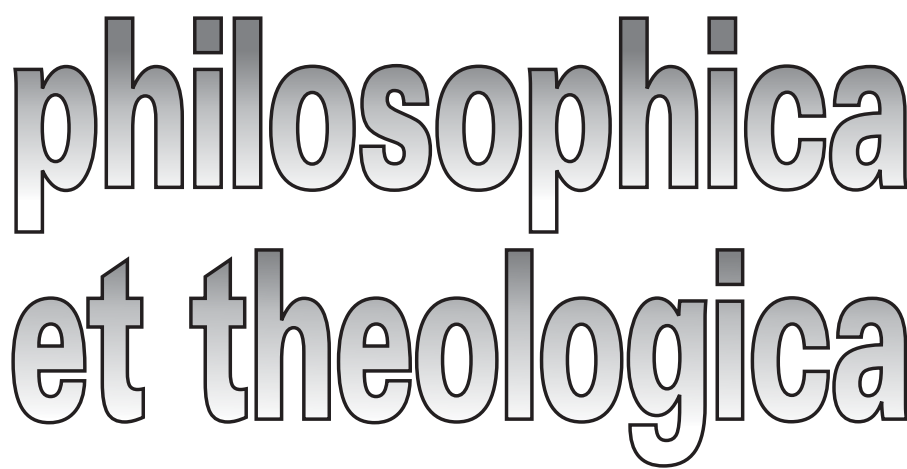

e-ISSN 2550-0589 p-ISSN 1412-0674

Editor in Chief

FX. Eko Armada Riyanto (Google Scholar; h-index: 5); Widya Sasana College of Philosophy Theology, Malang.

\section{Managing Editors}

Edison RL. Tinambunan (Google Scholar; h-index: 1); Widya Sasana College of Philosophy Theology, Malang.

Kurniawan Dwi Madyo Utomo (Google Scholar); Widya Sasana College of Philosophy Theology, Malang.

\section{Editorial Board}

Pius Pandor (Google Scholar; h-index: 2); Widya Sasana College of Philosophy Theology, Malang.

Valentinus Saeng (Google Scholar; h-index: 2); Widya Sasana College of Philosophy Theology, Malang.

Yohanes I Wayan Marianta (Google Scholar); Widya Sasana College of Philosophy Theology, Malang.

Raymundus Made Sudhiarsa (Google Scholar; h-index: 2); Widya Sasana College of Philosophy Theology, Malang.

Alphonsus Catur Raharso (Google Scholar; h-index: 2); Widya Sasana College of Philosophy Theology, Malang.

Petrus Maria Handoko (Google Scholar; h-index: 2); Widya Sasana College of Philosophy Theology, Malang.

Antonius Denny Firmanto (Google Scholar; h-index: 2); Widya Sasana College of Philosophy Theology, Malang.

Carl Sterkens (Scopus ID: ... ; Google Scholar; h-index: 7); Katholic Radboud University, Nijmegen, Niederlands.

Daniel Franklin Pilario(Google Scholar; h-index: 4); Adamson University, Manila, Philippines.

Roland Tuazon (Google Scholar; h-index: 2); Adamson University, Manila, Philippines.

Emanuel P.D. Martasudjita (Scopus ID: 6026801; Google Scholar; h-index: 4); Sanata Dharma University, Yogyakarta.

Johanis Ohoitimur (Google Scholar; h-index: 3); Pineleng College, Manado.

Antonius Eddy Kristiyanto (Google Scholar; h-index: 5); Driyarkara College, Jakarta.

Mudjia Rahardja (Scopus ID: ... Google Scholar; h-index: 10); Maulana Malik Ibrahim Islamic State University, Malang. Justinus Sudarminta (Google Scholar; h-index: 7); Driyarkara College, Jakarta.

English Language Advisor

Maria Lichmann (North Carolina)

Odilia Rahayu Widji Astuti

Indonesian Language Advisor

Didik Bagiyowinadi

Information and Technology

Imilda Retno Arum Sari

Publication Frequency

Studia Philosophicaet Theologica is published two times a year (April and October) 


\section{Studia Philosophica et Theologica}

\section{Author Guidelines}

1. Article must have150-word abstract in both English and Indonesian language and four or five keywords.

2. Article should be between 5000 and 8000 words, inclusive of references and footnotes.

3. Article must be a study based on either literary (text) or field research.

4. Article will be submitted in Word (single-spaced and 12-point font) for consideration by email attachment, beside online submission as required. Authors must $\log$ in before submit their article.

5. Headings:

- First-level headings (e.g. Introduction, Conclusion) should be in bold, with an initial capital letter for any proper nouns.

- Second-level headings should be in bold italics, with an initial capital letter for any proper nouns.

- Third-level headings should be in italics, with an initial capital letter for any propernouns.

6. Notes and Bibliographies please click https://www.dropbox.com/s/y2nb9l3cvb9 fg47/Notes\%20and\%20Bibliography\%20Turabian\%20Style.pdf? $d l=0$.

7. Article submitted will be peer-reviewed by qualified academics; this process may take weeks or months. All submitted papers are subject to review of the editors, editorial board, and reviewers.

8. Author should be willing to respond to questions from readers of their articles; and in case there is correction, author must refine the article as soon as possible.

\section{Guidelines for Book Reviews}

1. Please include, at the beginning: Author, Title, Place, Publisher, Date, number of pages, ISBN of the book reviewed.

E.g., Taylor, Charles. A Secular Age. Cambridge: The Belknap Press of Harvard University Press, 2007. 874+x pp. ISBN-13: 978-0-674-02676-6.

2. The review begin with abstract, three or four keywords and continue with a brief overall description of the book.

3. The review may include:

- The content and its complexity of the book.

- Comments on the author's style and contribution of the book.

- Philosophical or theological methodology of presentation.

- Position of the philosophical or theological arguments in its field.

4. The preferred format for submissions is MS-Word.

5. Review should be about 1500 words long. The name, affiliation and email address of the reviewer should appear at the end of the review. 


\section{Studia Philosophica et Theologica E-ISSN 2550 - 0589 \\ ISSN 1412-0674 \\ Vol. 21 No. 1 April 2021 \\ Hal. 1 - 131}

\section{DAFTAR ISI}

\section{ARTIKEL}

Pandemi Covid 19 dalam Perspektif Visi Kebangkitan

Paus Fransiskus

Martinus Dam Febrianto

$1-23$

Formasi Berkelanjutan: Membermaknakan Kekinian Imamat

Edison R.L. Tinambunan

Imajinasi untuk Merawat Kemanusiaan:

Pemikiran Martha Nussbaum dalam Pendidikan Humaniora

Cicilia Damayanti.....

Diskursus Hukum Kodrat dan Problem Pascamodernitas

Hizkia Fredo Valerian

$67-81$

Polemik Antara Original Event dan Original Purpose

dalam Liturgi: Spiritualitas Liturgi Ekaristi dalam Perspektif

Sejarah Liturgi dan Kitab Suci

Robert Pius Manik

$82-96$

Piet Go, Ensiklik Rerum Novarum dan Quadragesimo Anno dan Transformasi Moral Millenial

Godlif Sianipar.....

Applying Bardach and Patashnik's Policy Concept to Educational Leadership Development Effort in the Developing World

Gregorius Kukuh Nugroho 


\section{TELAAH BUKU}

Teologi Terlibat: Politik dan Budaya dalam Terang Teologi

Antonius Ignasius Nggino Tukan ................................................... 128 - 131 


\title{
IMAJINASI \\ UNTUK MERAWAT KEMANUSIAAN: \\ PEMIKIRAN MARTHA NUSSBAUM \\ DALAM PENDIDIKAN HUMANIORA
}

\author{
Cicilia Damayanti \\ Universitas Indraprasta PGRI \\ Email: ciciliadamayanti1@gmail.com
}

\begin{abstract}
Martha Nussbaum's education liberated everyone from narrow-minded. She uses imagination to embody her dream of equal democratic citizenship. Critical thinking will be useful to liberate everyone from unhuman traditions. For her, everyone must accept diversity and respected human dignity. Multiculturalism and cosmopolitanism were her important parts of humanities. Democratic education in her argument was necessary to build dialog and improved people's critical thinking and examine their lives. Besides that, philosophy will be needed to improve her humanities. Capabilities approach in her sight was a chance or free will in people's lives to be what they want and do whatever they wish for. And all of this can be reached through education and good health facilities.
\end{abstract}

Keywords: capabilities approach, cosmopolitan, democratic education, multiculturalism, narrative imagination.

\begin{abstract}
Abstrak
Pendidikan Martha Nussbaum membebaskan manusia dari kepicikan dan wawasan sempit. Dia menggunakan imajinasi untuk mewujudkan cita-cita masyarakat demokratis yang setara. Pola berpikir kritis sangat dibutuhkan bagi seseorang untuk lepas dari belenggu tradisi yang tidak manusiawi. Hal ini penting untuk menerima keragaman dan menghormati martabat kemanusiaan setiap orang. Multikulturalisme dan kosmopolitan menjadi bagian penting dalam pendidikan untuk merawat kemanusiaan. Pendidikan demokrasi dalam pandangannya memusatkan pendidikan pada dialog yang membantu seseorang untuk berpikir kritis dan menguji hidupnya. Filsafat berperan penting dalam membantu seseorang mempraktikkan kebijaksanaan dan mengkaji hidupnya. Dia menyatakan bahwa pendekatan kemampuan merupakan kesempatan atau kebebasan yang dimiliki setiap orang untuk bebas menjadi dirinya dan melakukan apa saja yang menjadi pilihannya. Dan hal ini didapat melalui pendidikan yang tepat dan sarana kesehatan yang memadai.
\end{abstract}


Kata Kunci: imajinasi naratif, kosmopolitan, multikulturalisme, pendekatan kemampuan, pendidikan demokrasi.

\section{Pendahuluan}

Martha Craven Nussbaum menegaskan bahwa pendidikan adalah jalan untuk membentuk pribadi dan menciptakan masyarakat beradab. ${ }^{1}$ Pendidikan humaniora menjadi programnya untuk menciptakan pribadi yang berbudi luhur dan bernalar kritis. Pribadi yang bermoral baik, berpikiran terbuka dan kritis dapat membentuk pribadi yang berkarakter kuat, cerdas, dan peduli sesama. Pribadi-pribadi manusia yang baik ini menjadi harapannya untuk membentuk masyarakat demokratis yang adil dan sejahtera. Pendidikan membuka cakrawala pikiran pribadi, untuk meluaskan pandangannya pada sesama dan dunia. Menurut pendapatnya, pendidikan hendaknya terbuka untuk mengembangkan kemampuan manusia, bukan hanya terpusat untuk meningkatkan pertumbuhan ekonomi nasional. ${ }^{2}$

Pendidikan humaniora membutuhkan seni untuk pembentukan karakter, dan imajinasi adalah jalan masuk untuk mengembangkan jiwa seni. Dua buku sumber utama yang dipakai adalah CultivatingHumanity: A Classical Defense of Reform in Liberal Education, yang terbit tahun 1997, dan Not for Profit: Why Democracy Needs The Humanities, yang terbit tahun 2010. Dengan tegas dia menyatakan hendaknya seni dikembalikan dalam kurikulum sekolah. ${ }^{3}$ Seni mengembangkan kemampuan pribadi untuk memiliki rasa ingin tahu dan menumbuhkan imajinasinya. Dia menegaskan bahwa daya imajinasi membantu seseorang meluaskan cakrawala dan wawasannya untuk kemudian memiliki kepekaan pada sesama. ${ }^{4}$ Pendidikan sejatinya adalah membebaskan manusia dari kepicikan dan untuk menerima keragaman. Artikel ini akan menjelaskan tentang pandangan pendidikan humaniora Nussbaum yang menggabungkan nalar kritis dan seni melalui imajinasi. Pendidikan demokrasi yang digagasnya menjadi landasan untuk membentuk masyarakat demokratis, yang mendukung kesetaraan. Berbicara tentang kesetaraan, menggambarkan bahwa tujuan pendidikan adalah untuk semua orang, termasuk bagi mereka yang dikucilkan oleh masyarakat atau negara. Dia juga menambahkan pendidikan demokrasi bermanfaat untuk menciptakan keadilan dan perdamaian dunia. Baginya masyarakat demokratis sangat penting untuk

1 Martha Craven Nussbaum, Cultivating Humanity: A Classical Defense of Reform In Liberal Education, (Cambridge: Harvard University Press, 1997), 4.

2 Martha Craven Nussbaum, Not For Profit: Why Democracy Needs The Humanities, (Princeton: Princeton University Press, 2010), 7.

3 Ibid, 8.

4 Ibid, 99. 
menciptakan keadilan dan perdamaian dunia. Sasaran pendidikannya adalah untuk semua manusia dari segala lapisan dan golongan, termasuk untuk kaum perempuan. ${ }^{5}$ Pendekatan kemampuan yang diuraikannya hendak menunjukkan pentingnya pengembangan kemampuan dalam hidup manusia. Imajinasi berperan penting bagi perkembangan jiwa setiap pribadi. Imajinasi naratif melahirkan empati dan bela rasa (compassion).

\section{Pendidikan Humaniora dan Tantangannya}

Martha Nussbaum melihat bahwa pendidikan saat ini berada di ujung tanduk. Hal ini selalu disampaikan dalam setiap seminar tentang pendidikan yang dihadirinya. Ada krisis tersembunyi (thesilentcrisis) yang harus segera dicarikan jalan keluarnya. Beberapa krisis itu antara lain:

\subsection{Pendidikan Terlalu Mengejar Keuntungan Semata (Profit)}

Perkembangan teknologi yang semakin pesat dan keberhasilan ekonomi yang menjadi tolok ukur kemajuan suatu negara, menyebabkan banyak negara menjadikan pendidikan sebagai pusat pengembangan ketrampilan setiap pribadi. Hal ini menjadikan lembaga pendidikan laksana pabrik untuk mencetak manusia yang siap pakai dalam bidang industri. Nussbaum menolak pendidikan yang hanya berpusat pada ekonomi, baginya pendidikan tidak mengejar keuntungan ekonomis semata (not for profit). Meskipun demikian, dia tidak menganjurkan untuk mengabaikan pengembangan teknologi. Dengan tegas, dia menyatakan bahwa pendidikan itu harus dapat menggabungkan ketrampilan dan kemanusiaan. Hidup berdemokrasi, menurutnya, membantu setiap orang untuk menerima keragaman dan menghormati martabat kemanusiaan. Demokrasi yang dikembangkan dengan tepat dapat menciptakan kebudayaan yang mengajak setiap orang bekerja sama untuk mengatasi masalah global yang mendesak. ${ }^{6}$

\subsection{Imajinasi Yang Mulai Menghilang Dalam Pendidikan}

Menurutnya, pendidikan saat ini terpusat pada pembelajaran terapan (applied learning) dan tidak menyentuh dasar pengetahuan (basic scientific) itu sendiri. Inti humanisme pendidikan seperti seni dan nalar kritis tidak ada (basically absent), sebab pendidikan jatuh pada keuntungan ekonomi. ${ }^{7}$ Nussbaum menyatakan bahwa jiwa (soul) pendidikan terpusat pada pemikiran dan imajinasi yang dikembangkan untuk merawat kemanusiaan. Imajinasi membuat setiap orang memiliki kemampuan untuk menghargai martabat

5 Nussbaum, Cultivating Humanity, 14-9.

6 Nussbaum, Not For Profit, 6.

7 Ibid, 3. 
kemanusiaan yang menjadi landasan dalam hidup masyarakat demokratis. Pendidikan humaniora yang digagasnya menawarkan keseimbangan antara pendidikan yang bertujuan mencari keuntungan dan pendidikan humanitas untuk mencetak warga negara yang demokratis. Dan menurutnya, imajinasi sangat penting untuk dikembangkan kembali dalam pendidikan. Berkaitan dengan hal ini, Nussbaum berkata:

Saya berusaha untuk menunjukkan betapa pentingnya humanitas dan seni dalam pendidikan dasar/menengah dan perguruan tinggi, dan mencoba menggambarkannya dalam berbagai tahapan dan tingkatan yang berbeda. Saya tidak meragukan betapa sains dan ilmu sosial, khususnya ekonomi, juga penting untuk mendidik masyarakat. Dan tidak ada yang menganjurkan untuk meninggalkan ilmu-ilmu tersebut. Fokus saya kemudian adalah pada apa yang berharga dan sangat terancam punah. ${ }^{8}$

\subsection{Pendidikan Demokrasi Yang "Mati Suri" (Democratic Education on the Ropes)}

Hilangnya pendidikan humaniora menyebabkan pengetahuan budaya sebagai penyokong masyarakat demokratis tidak menjadi perhatian utama dalam pendidikan. Krisis ekonomi yang sempat menghantam dunia internasional menyebabkan pemotongan dana dalam bidang budaya dan seni, bahkan dihilangkan sama sekali dari program pendidikan. Orientasi pendidikan pada ekonomi menyebabkan sistem pembelajaran bertumpu pada permintaan pasar global yang membutuhkan tenaga siap pakai, sehingga pendidikan terpusat pada pendidikan ilmiah dan teknis. Mengutip Drew Faust, menurut Nussbaum, pendidikan humaniora berada di ambang krisis, karena tidak mendapat dukungan dari dalam maupun luar.

Pendidikan tinggi dapat menawarkan kedalaman dan keluasan penglihatan yang tidak ada pada saat rabun jauh yang tak terhindarkan bagi diri seseorang dan masyarakat. Manusia membutuhkan makna, pemahaman, dan perspektif serta bekerja. Pertanyaannya bukan pada apakah kita mampu percaya pada tujuan seperti itu di masa-masa ini, tetapi apakah kita mampu untuk tidak melakukannya. ${ }^{9}$

Kritik-kritik Nussbaum ini memperlihatkan bahwa pendidikan humaniora merupakan sampingan yang boleh tidak diajarkan. Sementara baginya, pendidikan berperan penting dalam menyeimbangkan pikiran dan hati seseorang.

Nussbaum yang terinspirasi Seneca menyatakan bahwa pendidikan hendaknya membebaskan sehingga dapat menciptakan masyarakat yang merdeka (freecitizen) dan "berani mengemukakan pendapatnya" (call their minds their own). Menurutnya, pendidikan bertugas untuk menyiapkan seseorang menjadi warga negara yang menerima keragaman dan mampu

8 Ibid, 7.

9 Ibid, 123-4. 
bekerja sama secara global. Warga negara yang memahami, menghormati, dan membangun komunikasi untuk kerja sama internasional yang dapat mengatasi permasalahan global, sehingga tercipta perdamaian dunia. Pendidikan yang mengedepankan sikap saling menghargai pendapat dan penyelidikan diri kritis untuk membangun budaya demokratis yang penuh pertimbangan dan reflektif. Mengutip pendapat Sokrates, baginya, menyiapkan setiap orang untuk menjadi warga negara berarti mengajarkan tentang hal yang tidak diketahuinya, dan untuk mengatasi masalah tersebut. Mereka perlu diajarkan untuk membuat argumentasi kritis dan tersusun dengan tepat, sehingga dapat menciptakan masyarakat yang berani dalam mengemukakan pendapatnya. Dia menghendaki agar demokrasi tetap dilestarikan dalam pendidikan, dengan mengembangkan dialog dan debat terbuka. Sebab, orang yang tidak menggunakan nalar dan imajinasi tidak akan siap menerima keragaman dalam hidup bermasyarakat dan menjadi miskin secara pribadi dan politik, meskipun memiliki keahlian tertentu. ${ }^{10}$

Metode pengujian hidup ala Sokrates, menurut Nussbaum, menjadi cara untuk menghasilkan argumen kritis sebagai cara menghargai kebebasan masyarakat dalam hidup demokratis. Argumentasi menjadi sarana penting bagi kebebasan warga, yang dapat melepaskan prasangka untuk menjaga keadilan. Analisis logis menjadi kunci utama untuk budaya politik demokratis, sehingga demokrasi reflektif dan setara dapat terwujud. Setiap warga negara hendaknya mempunyai kapasitas untuk mempertanyakan keyakinannya, dan bukan untuk kepentingan persaingan ekonomi semata. ${ }^{11}$ Dia menambahkan bahwa imajinasi dapat mengembangkan pendidikan demokrasi untuk menerima keragaman dan menghormati nilai kemanusiaan, sehingga kesetaraan yang menjadi pembaharuannya dalam pendidikan humaniora dapat terwujud. Seseorang dapat melepaskan diri dari belenggu wawasan yang terbatas dan kebiasaan hidupnya. Masyarakat yang memiliki kemampuan melampaui nasionalisme sempit dan menerima keragaman identitas, asal negara, kelas, ras, dan gender. Argumentasi kritis dan analisis logis membantu setiap orang untuk dapat menghargai kebebasan dan menerima keragaman manusia. Untuk menancapkan keyakinan bahwa setiap manusia layak untuk dihormati martabatnya. ${ }^{12}$ Menurutnya, pendidikan perlu merombak kurikulumnya untuk:

...menciptakan warga negara yang dapat menggunakan nalarnya untuk melihat perbedaan dan orang asing bukan menjadi ancaman, tetapi menjadi undangan untuk menjelajah dan memahami dunia, memperluas cakrawala dan kapasitasnya sebagai warga negara dunia ${ }^{13}$.

\footnotetext{
10 Nussbaum, Cultivating Humanity, 293-7.

11 Ibid, 19.

12 Ibid, 53-8.

13 Ibid, 301.
} 
Pendidikan humanioranya juga melingkupi pelajaran tentang kajian gender, rasis dan etnis, serta minoritas seksual bagi mahasiswa. Kajian tentang gender, rasisme, etnisme, dan minoritas seksual dapat dijadikan mata kuliah yang mengembangkan pemahaman dan kewarganegaraan untuk semua mahasiswa dan cendekiawan. Minoritas perlu diberi ruang untuk menegaskan identitas mereka. Imajinasi bisa menjadi solusi untuk mengatasi masalah kesenjangan sosial, dan universitas sebaiknya menciptakan kelas yang jamak dan umum. Pendidikan humaniora sebaiknya memusatkan perhatian dalam mengangkat masalah sosial kemanusiaan secara khusus, terkait dengan lintas regional dan nasional. Teori keadilan sosial adalah teori untuk semua manusia, dan hal ini tidak boleh dilupakan. ${ }^{14}$

Nussbaum menambahkan bahwa melalui penyelidikan mendalam dan menyeluruh tentang sejarah dunia, terbuka pandangan bahwa budaya Timur sudah sejak lama memiliki akar nilai-nilai kemanusiaan. Ashoka adalah Raja dari India yang mempelajari tentang Budha, dan mengikuti keyakinan itu. Dia membangun prasasti besar untuk rakyatnya yang berisi aturan-aturan tentang perilaku pribadi yang berkeutamaan untuk mengatur hidup bersama. Isi prasasti tersebut menekankan untuk menghargai dan menghormati nilai keragaman dan menjaga toleransi. Sultan Moghul, Akbar (1556-1605), membuat kebijakan tentang HAM termasuk tentang kebebasan beribadah dan menjalankan agama. Alberuni (abad 11), penulis dari Iran, melakukan penjelajahan ke India untuk menerjemahkan risalah-risalah matematika India yang berpengaruh pada dunia Arab, kemudian dipakai dalam mengembangkan matematika di dunia Barat. Penyelidikan sejarah dunia ini menunjukkan bahwa budaya toleransi dan HAM yang dianggap sebagai hasil budaya Barat sebenarnya berakar dalam budaya Timur. Di sini terlihat bahwa budaya itu berkaitan satu sama lain. Tidak ada superioritas dalam budaya dan penyelidikan kritis hendaknya terus dilakukan untuk menghindari sejarah yang dimanipulasi. ${ }^{15}$

Terinspirasi pandangan Sokrates untuk menerima kemajemukan, menurut Nussbaum, pendidikan humaniora dan warga dunia berkaitan satu dengan yang lain. Hubungan kedua hal ini disebut kosmopolitan (cosmopolitan). Dunia global yang dihadapi saat ini menjadikan dunia sebagai satu rumah bersama. Konsep kosmopolitan yang diuraikannya berasal dari kaum Stoic yaitu Kosmoupolites, di mana konsep utamanya adalah bentuk kesetiaan setiap anggota masyarakat kepada sesamanya ${ }^{16}$. Kosmopolitan ini kemudian disebut sebagai warga negara dunia (citizens of the world), yang menurut pendapatnya sangat penting untuk dimasukkan ke dalam kurikulum pendidikan, terutama

14 Martha Craven Nussbaum, "Humanities and Human Development", The Journal of Aesthetic Education, Vol. 36, No. 3 (Konten ini diunduh dari http://www.jstor.org/stable/3333596, 2002), 44.

15 Nussbaum, Cultivating Humanity, 142-7. 
di perguruan tinggi.

Pendidikan kosmoupolites sangat berhubungan dengan penyelidikan Sokrates dan keberhasilan hidup yang teruji (theexaminedlife). Untuk menjadi bagian masyarakat dunia dibutuhkan kesediaan untuk meragukan kebiasaannya sendiri dan masuk ke dalam argumen kritis untuk pilihan etis dan politisnya. Dengan dialog dan argumen yang semakin disempurnakan, setiap peserta dalam diskusi terbuka ini hendaknya memiliki kemampuan untuk membedakan, tradisi mereka sendiri, dari yang membatasi sampai yang dapat dipuji sebagai norma bagi orang lain, dari yang sewenang-wenang dan tidak dapat dibenarkan sampai pada yang dapat dibenarkan dengan argumen kritis ${ }^{17}$.

Multikulturalisme hendak dikembangkan melalui dialog dan diskusi. Skeptisisme hendaknya dihindari, dengan cara menjaga toleransi dan menghargai budaya yang berbeda satu sama lain. Dengan bantuan kisah Herodotus, Nussbaum memperlihatkan budaya lain yang memperkaya wawasan masyarakat. Herodotus pergi ke Mesir dan Persia dengan pikiran yang penuh dengan pertanyaan, untuk lebih mengeksplorasi budaya asing tentang ilmu pengetahuan, moral, dan ide-ide politik. Penemuan ini sangat mengejutkannya karena ternyata wawasan yang dimiliki bangsa tersebut melampaui wawasan masyarakat bangsanya ${ }^{18}$. Pelatihan yang menarik perlu diadakan agar mahasiswa berminat menjelajah hal-hal baru dengan mewujudkan petualangan menyenangkan dalam pelajaran lintas budaya. Mahasiswa diajak untuk membuka pikirannya akan dunia yang luas, sehingga melahirkan kesadaran bahwa budaya lain dapat memperkaya budayanya. Nussbaum menentang relativisme budaya. Baginya, nilai kemanusiaan lebih penting daripada adat istiadat yang membelenggu hidup manusia. Budaya menjadi jalan untuk manusia agar dapat membandingkan apa yang dilihat dan apa yang ada dalam konsep pikirannya, tentang apa yang baik untuk kemudian dikembangkannya lagi. ${ }^{19}$

Merawat kemanusiaan dan membentuk masyarakat yang bertanggung jawab menjadi kunci utama pendidikan humaniora di level pendidikan tinggi. Pendidikan ini bertujuan untuk menciptakan manusia yang memiliki kepekaan

16 M. Ayas Naseem and Emery j. Hyslop-Margison, “Nussbaum's Concept of Cosmopolitanism: Practical Possibilityor Academic Delusion?", Paideusis. Vol. 15 - No. 2 (Konten ini diunduh dari https://journals.sfu.ca/pie/index.php/pie/article/view/75/25Eved=2ahUKEwi9m, 2006), 52.

17 Nussbaum, Cultivating Humanity, 62.

18 Ibid, 134.

19 Martha Craven Nussbaum, "Compassion: The Basic Social Emotion", dalam Social Philosophy and Polici Foundation, Vol. 13 - Issue 1 (Konten ini diunduh dari https://people.whitman.edu/ $\sim$ frierspr/nussbaum\%25201996\% 2520compassion.pdfEved=2ahUKEwiaz-7Cq6zuAhXNX isKHV99CkEQFjADegQIBBABEusg=AOvVaw1XFcA40U-AH-qVSqkGoKXqEcshid= 1611208591114, 1996), 51.

20 Alison Cook-Sather, "Students as Learners and Teachers: Taking Responsibility, Transforming Education, and Redifining Accoutability", Curriculum Inquiry. Vol. 40 - No. 4 (Konten ini diunduh dari http://www.jstor.org/stable/40962986, 2010), 562. 
dan ketajaman berpikir sebagai masyarakat dunia. ${ }^{20}$ Dan untuk menciptakan masyarakat demokratis sebagai tujuan dari pendidikan humaniora, dibutuhkan kemampuan yang penting untuk mewujudkannya. Nussbaum menjelaskan tentang kemampuan dalam tiga (3) bagian. Pertama, kemampuan kritik diri dan nalar kritis tentang tradisi dan budaya sendiri, seperti yang diajarkan Sokrates (Nussbaum. 2009, 30). Kedua, kemampuan untuk menerima dan menghargai keragaman, memahami perbedaan sejarah dan karakter budaya yang ada di dunia. ${ }^{21}$ Ketiga, kemampuan yang memadukan kedua kemampuan tersebut, yaitu imajinasi naratif. Kemampuan untuk berpikir bagaimana rasanya berada dalam posisi orang lain (tobe in the shoes of a person different from one self), menjadi pembaca yang cerdas pada cerita orang lain, untuk memahami emosi, harapan, dan hasrat yang dimiliki seseorang. Pengembangan simpati, yang menjadi kunci utama dari gagasan modern pendidikan yang berkualitas. ${ }^{22}$

Inti dari ketiga kemampuan ini adalah refleksi diri kritis akan nilai-nilai budaya dan kebijakan publik, sehingga hidup multikultural untuk menghargai dan menerima keragaman manusia dapat diwujudkan. Hidup multikultural menggerakkan manusia untuk berpikir kritis dalam mewujudkan masyarakat demokratis, di mana musyawarah mufakat menjadi landasan hidup moral dan politik yang baik. Pendidikan humaniora yang dicita-citakan adalah hidup yang teruji, sesuai anjuran Sokrates. Masyarakat demokratis dapat diwujudkan melalui penggunaan nalar secara kritis. Sikap kritis berarti tidak hanya manut (patuh) dan pasif tetapi juga mampu bekerja sama untuk menentukan pilihan sendiri, lepas dari bayang-bayang penguasa. Universitas berperan penting untuk membentuk manusia muda yang berani berpikir dan mengungkapkan pendapatnya serta menghargai pendapat orang lain. ${ }^{23}$

Multikulturalisme adalah masyarakat yang menyadari bahwa dirinya merupakan bagian dari masyarakat dunia, yang membangun imajinasi dalam pikirannya tentang ide-ide kepuasan. Pandangan ini membantu masyarakat melihat kenyataan hidup di luar kehidupannya, tanpa harus kehilangan identitas diri. Mahasiswa perlu diajarkan tentang dasar-dasar sejarah dunia. Mereka perlu mendalami setidaknya satu budaya lain yang tidak dikenalnya, untuk mengeksplorasi rasa ingin tahunya dan lebih rendah hati melihat perannya di dunia. Mereka sebaiknya menguasai satu bahasa asing yang merupakan upaya untuk memahami budaya lain. Bahasa itu tidak saja

21 Martha Craven Nussbaum, "Tagore, Dewey, and the Imminent Demise of Liberal Education", The Oxford Handbook of Philosophy of Education, Harvey Siegel. Ed. (Oxford: Oxford University Press, 2009), 31-2.

22 Ibid, 32.

23 Martha Craven Nussbaum, "Liberal \& Global Community", Liberal EducationVol 90 - No. 1, (Konten ini diunduh dari https://files.eric.ed.gov/fulltext/EJ728534.pdfEved=2ahUKEwj Fyt2krKzuAhX863MBHWj8DZEQFjACegQIChACEusg=AOvVaw3zK1SspzZffWLPd4iPTVM5, 2004), 43. 
menjadi alat komunikasi, tetapi menjadi jalan masuk untuk memahami budaya dan kebiasaan hidup sehari-hari orang lain. Orang muda perlu didorong untuk mempelajari bahasa asing untuk bisa menilai budaya lain. ${ }^{24}$ Penyelidikan lintas budaya membuka cakrawala pemikiran manusia bahwa pandangan tentang yang alami (natural) ternyata terbatas dan merupakan kebiasaan. Tindakan mempertemukan budaya lain tanpa prasangka dapat menumbuhkan kesadaran bahwa semua tradisi merupakan ciptaan manusia pada waktu dan tempat tertentu. Pendidikan humaniora bertujuan untuk menciptakan masyarakat adil dan sejahtera, di mana kaum muda menjadi pusat perhatiannya. Mereka hendaknya didukung untuk bersikap kritis terhadap kebiasaan budayanya. Hasil yang hendak dicapai adalah memecahkan masalah dalam ranah publik untuk membebaskan imajinasi yang picik. ${ }^{25}$ Kemanusiaan merupakan nilai keutamaan yang mengajak setiap orang untuk berbuat baik, bertindak adil, dan bermurah hati pada sesamanya. Tugas setiap orang adalah untuk mendahulukan kesejahteraan umum, serta menahan diri untuk tidak menyakiti dan melindungi sesamanya dari ketidakadilan. ${ }^{26}$

Pengembangan imajinasi merupakan gagasan penting untuk pendidikan humaniora. Kemampuan ini mengajak setiap pribadi untuk peduli pada sesama serta mengembangkan kekaguman dan keingintahuannya pada banyak hal. Sastra dan seni merupakan sarana untuk mengembangkan imajinasi. Pribadi yang mengembangkan imajinasinya lebih mudah untuk peduli dan peka pada kebutuhan orang lain. Imajinasi dalam pandangannya melahirkan empati karena membayangkan bagaimana rasanya berada dalam posisi orang lain.

\section{Imajinasi Naratif}

Imajinasi naratif dalam pandangan Nussbaum merupakan kemampuan ketiga untuk mengajak setiap orang berempati pada penderitaan orang lain. Kemampuan untuk membayangkan bagaimana rasanya dalam posisi orang lain, membuat seseorang menggerakkan hati dan pikirannya untuk memiliki kepedulian dan kepekaan. Imajinasi naratif mengajak pembaca membuka wawasannya ketika membaca kisah orang lain, untuk memahami emosi, harapan, dan hasrat seseorang dalam hidupnya. ${ }^{27}$ Dia menambahkan,

24 Ibid, 44-5.

25 Jeffrey Roth, "Can The Balmof Stoicism Salve the Wound of Multiculturalism? A Review of Martha C. Nussbaum, "Cultivating Humanity: A Classical Defense of Reform in Liberal Education", Journal of Thought. Vol. 35 - No. 1 (Konten ini diunduh dari http://www.jstor.org/ stable/42589600, 2000), 12.

26 Marilyn Friedman, "Educating for World Citizenship". Dalam Ethics. Vol. 110 - No. 3 (Konten ini diunduh dari https://www.jstor.org/stable/10.1086/233325, 2000), 591.

27 Nussbaum, "Liberal \& Global Community", 45. 
imajinasi penting dikembangkan sejak dini, sebab dapat mengajarkan kepada anak-anak tentang kasih dan penderitaan orang lain. ${ }^{28}$

Pendidikan humanioranya dibutuhkan untuk menjadi bagian sebagai warga negara dunia (cosmopolitanism). Pemahaman imajinatif tentang motivasi, kepekaan, dan pilihan orang yang berbeda budaya membantunya melihat dunia dari sudut pandang orang lain. Sastra dan seni berperan penting dalam menumbuhkan imajinasi dan rasa ingin tahu tentang budaya lain. ${ }^{29}$ Nussbaum menegaskan bahwa karya sastra membantu mengembangkan imajinasi seseorang. Sebab, sifat manusia yang terkadang sulit dipahami dan terkesan abstrak dapat dipelajari melalui kisah sastra yang dinamis. Dalam kisah sastra ada pengakuan terhadap kemanusiaan orang lain, imajinasi membantunya merasakan apa yang dirasakan tokoh tersebut. Imajinasi membangkitkan kesadaran bahwa sekuat dan semampu apa pun mereka tetap membutuhkan orang lain. Hal ini didapatnya melalui pendidikan yang menumbuhkan imajinasi naratif terhadap penderitaan orang lain. ${ }^{30}$ Kenyataan bahwa dirinya rapuh membantunya memiliki perasaan bela rasa dengan berpikir, "Bagaimana bila hal itu terjadi pada saya, dan bagaimana saya ingin diperlakukan."Emosi bela rasa (compassion) mengajak untuk menyadari kerapuhan kita, untuk melihat bahwa orang lain itu bisa jadi adalah diri kita sendiri.Imajinasi empati digunakan untuk mengatasi pandangan nasionalisme sempit yang berbasis ras, gender, dan orientasi seksual berbeda. Bela rasa dapat dikembangkan melalui kisah fiksi imajinatif, sebab orang tidak mungkin mengubah ras yang sudah menjadi bawaannya. Dengan memiliki relasi yang cukup dekat dengan orang yang berbeda ras dan orientasi seksualnya, orang dapat membayangkan bagaimana rasanya apabila orang yang disayangi memiliki kehidupan seperti itu. ${ }^{31}$

Pandangan Nussbaum tentang imajinasi merupakan gabungan antara simpati dan penyelidikan Sokrates, sehingga menjadi landasan bagi kehidupan demokratis yang sehat. Anak-anak pada dasarnya memiliki kapasitas simpati dan kepedulian. Namun, ada sisi narsisme anak yang membuat mereka menjadi egois, dan mereka dapat dilatih untuk tetap memiliki hati yang tulus. Donald Winnicott, seorang dokter anak dan psikoanalisis, sebagaimana dirujuk Nussbaum, menegaskan bahwa orang tua berperan penting dalam perkembangan anak. Baginya, setiap anak harus mendapatkan kasih sayang lengkap dari ayah dan ibunya, sehingga dapat berkembang dengan baik emosi dan pikirannya. Bermain bersama membangun ikatan kuat antara orang tua dan anak. Dalam bermain, anak dapat mengembangkan kemampuan imajinasinya. Winnicott menyebutnya sebagai "dunia khayalan" (potential

28 Nussbaum, Not For Profit, 93.

29 Naseem and Hyslop-Margison, Nussbaum's Concept of Cosmopolitanism, 54.

30 Nussbaum, "Liberal \& Global Community", 45.

31 Nussbaum, Cultivating Humanity, 90-2. 
space), dunia yang membuat anak bebas berkreasi dalam pikirannya. Dalam dunia ini, skenario buatan mereka membuatnya mengembangkan kepekaan dan kepedulian pada sekitarnya. Pada masa ini, anak memiliki objek pengganti (transitionalobject) dari orang tuanya, yaitu mainan atau selimutnya. Mainanmainan ini menjadi objek yang diberkahi kehidupan olehnya agar dapat diajak bermain bersama, sehingga tidak tergantung lagi pada orang tuanya. ${ }^{32}$

Permainan menjadi sarana bagi anak-anak mengembangkan rasa ingin tahu dan takjub dalam hidup mereka. Dongeng anak merupakan salah satu sarana untuk mengembangkan kemampuan imajinasinya yang melahirkan empati. Bagi Nussbaum, lagu anak seperti Bintang Kecil (Twinkle, Twinkle, Little Star) dapat menumbuhkan rasa takjub anak-anak akan kehidupan lain di sekitarnya. Kisah fantasi mengembangkan kemampuan kreatif anak-anak: saat mereka memandang bulan dan menganggapnya seperti wajah, berbicara kepada bintang seperti dengan teman, dan untuk menggambarkan kembali tentang seekor sapi yang dilihat dengan bahasanya sendiri. Niat untuk berbagi dan kasih, seperti yang tertulis dalam dongeng, adalah persiapan untuk berbagi hal yang lebih besar dalam hidup nyata. Persepsi membuat anak-anak membayangkan objek fisik dapat bergerak dalam pikirannya. Fantasi memiliki kaitan dengan persepsi seseorang. Menurutnya, lagu anak (nurserysong) seperti juga lagu yang lainnya, menumbuhkan segi kemanusiaan dan persahabatan, bukan sentimen ketakutan terhadap hal asing di langit. Lagu itu mengajak anak untuk melihat bintang bagaikan berlian dan bukan peluru yang merusak. Dan hal ini membangun sikap moral yang baik untuk hidup demokratis. ${ }^{33}$

Winnicott, yang dikutipnya, menegaskan bahwa permainan tidak akan hilang saat orang semakin dewasa. Orang dewasa dapat menggunakan permainan untuk menguatkan hubungan dengan pasangannya. Relasi seksual dan keintiman adalah wilayah yang membutuhkan permainan untuk tetap menghidupkan komitmen bersama. Empati yang terbentuk melalui imajinasi dan permainan membuat hubungan mereka dekat, dapat melepaskan egoisme masing-masing, dan mengembangkan kemampuan berbagi. Menurut Nussbaum, Winnicott memanfaatkan permainan untuk menjaga komitmen dengan istrinya:

Permainan merupakan sarana bagi Winnicott menguatkan hubungan dengan istrinya, sehingga tidak membutuhkan terapi pernikahan. Dia dan istrinya sangat terkenal karena gurauan dan candaan mereka; catatannya berisi gambar-gambar konyol dan puisi-puisi yang mereka tulis saat sedang bosan dalam rapat ${ }^{34}$.

Masyarakat demokratis yang setara dan sejahtera adalah cita-cita

32 Nussbaum, Not For Profit, 97-8.

33 Martha Craven Nussbaum, The Poetic Justice: The Literary Imagination and Public Life, (Boston: Beacon Press, 1995), 38-9.

34 Nussbaum, Not For Profit, 100. 
Nussbaum. Baginya pendidikan dibutuhkan untuk mempersiapkan seseorang menghadapi dunia global. Demokrasi merupakan sistem yang memberi kesempatan bagi setiap orang untuk mengungkapkan pendapat dan menghargai pendapat yang lainnya. Pendidikan demokrasi mengembangkan pola berpikir kritis dan dialog untuk membangun argumentasi yang sehat.

\section{Pendidikan Demokrasi}

Demokrasi menjamin kesejahteraan dan menciptakan keadilan dalam masyarakat. Namun, yang menjadi keprihatinannya adalah saat membicarakan tentang kesejahteraan, acuan dan penilaian tentang kesejahteraan berbeda-beda pada setiap negara. Tetapi, nilai ekonomi menjadi pandangan yang menyatukan tentang kesejahteraan manusia. Saat berbicara tentang kesejahteraan suatu bangsa, pusat perhatian tertuju pada seberapa tinggi tingkat pertumbuhan ekonominya. Bagi Nussbaum, hal inilah yang membuat kualitas hidup seseorang tidak menjadi prioritas. Kesejahteraan baginya bukan terletak pada keuntungan ekonomi, tetapi pada seberapa baiknya distribusi sosial dalam negara itu, pendidikan dan kesehatan yang merata bagi warganya. Demokrasi stabil dapat diwujudkan saat setiap warganya bisa memandang sesamanya sebagai manusia yang bermartabat dan setara, tanpa membedakan agama, ras, dan gender. ${ }^{35}$

Pendidikan humaniora yang digagas Nusbaum menjadi angin segar untuk memperbaiki sistem pendidikan yang cenderung membelenggu kebebasan berekspresi. Menurut pendapatnya, pendidikan bertujuan untuk membentuk manusia-manusia yang siap menghadapi dunia global, menciptakan masyarakat yang cerdas untuk memecahkan masalah umum dan global. Dia percaya bahwa pendidikan dapat mengubah hidup seseorang. Pendidikan demokrasi dapat menciptakan masyarakat demokratis yang sehat, masyarakat yang mampu menghargai perbedaan pendapat dan membangun dialog kritis. Metode Sokrates, menurut Nussbaum sangat penting untuk dikembalikan ke dalam pendidikan. Sebab metode ini menciptakan manusia-manusia yang bernalar kritis dan berani mengeluarkan pendapat berdasarkan bukti-bukti terpercaya. ${ }^{36}$ Metode ini dipercaya dapat mengembangkan kemampuan berpikir kritis. Pengujian diri menjadi jalan bagi seseorang untuk menggunakan nalar dan menguji hidupnya (examinedlife). Saat berdialog, Sokrates selalu menganggap dirinya tidak tahu apa-apa (eironeia). Dia akan bertanya dan terus bertanya kepada lawan bicaranya sehingga melahirkan kesadaran bahwa sebenarnya mereka kurang mengerti. Pandangannya menyatakan bahwa dalam jiwa setiap orang sudah terkandung pengertian untuk dibantu dikeluarkan. Ibunya yang bidan membantunya mengembangkan teknik

35 Ibid, 14.

36 Nussbaum, Cultivating Humanity, 14-9. 
kebidanan (maieutike), untuk mengeluarkan kecerdasan dalam diri seseorang. ${ }^{37}$

Nussbaum menambahkan bahwa filsafat dibutuhkan dalam pendidikan demokrasi yang mendukung ilmu kemanusiaan (humanities). Mengutip Sokrates, menurutnya, filsafat hendaknya membumi sehingga dapat menjangkau banyak orang untuk berargumentasi kritis. Filsafat menjadi jalan untuk mempraktikkan kebijaksanaan dan mengkaji hidup manusia. Pendidik berperan penting dalam mengajarkan seseorang untuk memiliki pendirian teguh dan tidak mudah digoyahkan. Mereka hendaknya mengajarkan pentingnya menghargai pendapat orang lain, karena setiap orang berhak untuk berpendapat. Setiap orang sebaiknya menguji hidupnya, sebab hidup yang tahan uji layak untuk dihayati. ${ }^{38}$ Dan menurutnya saat ini banyak kaum muda mulai tertarik mempelajari filsafat. Oleh karena itu sebaiknya filsuf mulai mengubah teknik pengajarannya, sehingga pelajaran filsafat dapat diterima oleh semua kalangan. Akan lebih baik bila metode pengajarannya mulai diarahkan pada analisis dan mengkritisi peristiwa-peristiwa dan ideide yang sedang berkembang dalam masyarakat. Hal ini akan sejalan dengan pandangan Sokrates yang menyebut filsafat sebagai provokator untuk membantu seseorang membangun argumen kritis dalam diskusi dan dialog terbuka. ${ }^{39}$ Pendidik yang memiliki hati dan peduli sangat dibutuhkan dalam pendidikan humanioranya. Mereka diharapkan mampu menghidupkan dan mengembangkan pola berpikir kritis. Pendidik sebaiknya dapat memberikan beragam bacaan bermutu yang dapat meningkatkan nalar untuk membuat argumen kritis. Filsafat penting untuk kemajuan pendidikan humaniora atau ilmu-ilmu sosial lainnya, dan hendaknya disesuaikan dengan kebutuhan faktual seseorang. Simpati mereka dikembangkan melalui kemampuan untuk peka dan peduli pada masalah-masalah kemanusiaan global. Dan ini mewujudkan mimpi dan harapan Sokrates untuk membuat filsafat membumi. ${ }^{40}$

Berbicara tentang demokrasi dan metode Sokrates kurang lengkap tanpa menambahkan pendapat RabindranathTagore dari India. Nussbaum sangat mengagumi pemikiran Tagore dalam pendidikan, yang mengembangkan pola berpikir kritis dan menyeimbangkannya dengan pendidikan seni. Seperti Dewey yang berpendapat seni sangat penting untuk hidup demokratis, Tagore pun melihat seni dibutuhkan untuk mengembangkan simpati yang mewujudkan kesetaraan dalam demokrasi. Menurut mereka, kapasitas untuk bersimpati dikembangkan untuk merawat kemanusiaan. Kapasitas ini didapat

37 A. Sudiarja. ed., Karya Lengkap Driyarkara: Esai-Esai Filsafat Pemikir yang Terlibat Penuh Dalam Perjuangan Bangsanya. (Jakarta: Gramedia Pustaka Utama, 2006), 1139.

38 Nussbaum, Not For Profit, 48-51.

39 Nussbaum, Cultivating Humanity, 18-21.

40 Ibid, 40-1. 
dengan mengembangkan pendidikan yang berpusat pada pembelajaran global, seni, dan kritik diri Sokrates. Tagore, yang dikutipnya, memahami pentingnya seni dalam pengembangan pribadi manusia. Perpaduan metode Sokrates dan seni adalah aspek penting dalam pendidikan yang membantu perempuan dan laki-laki mewujudkan kemampuan mereka. ${ }^{41}$

Pendidikan demokrasi yang hendak dikembangkannya bertitik tolak pada pengembangan kemampuan imajinatif dan kesadaran bahwa sesamanya (fellowcitizen) adalah orang-orang yang memiliki hak setara. Kesetaraan adalah kata kunci untuk mewujudkan keadilan sosial. Pendidikan sangat dibutuhkan untuk mengubah hidup seseorang. Sementara itu banyak perempuan, khususnya di negara berkembang, kurang mendapat perhatian yang layak. Kesetaraan baginya adalah kesempatan bagi perempuan untuk mendapat pendidikan yang dapat mengubah hidupnya. Nussbaum menegaskan, sasaran pendidikannya adalah untuk semua orang. Semua orang di sini mengacu pada pandangan Sokrates yang mengatakan setiap orang berhak mendapatkan pendidikan. Pendidikan untuk semua orang dipertegas kembali oleh kaum Stoic, yaitu pendidikan yang setara, baik itu perempuan, budak, maupun orang-orang miskin dan yang terpinggirkan. ${ }^{42}$ Bagi Nussbaum, pendidikan bertujuan untuk mengembangkan kemampuan (capabilities) manusia sebagai pembelajar. ${ }^{43}$ Kemampuan menjadikan manusia dapat meraih haknya dalam hidup bermasyarakat. Negara yang adil adalah negara yang dapat meningkatkan kemampuan, khususnya bagi seseorang untuk mengembangkan dirinya dalam masyarakat.

\section{Pendekatan Kemampuan (Capabilities Approach)}

Pendekatan kemampuan Nussbaum terpusat pada kualitas hidup manusia yang menjadi tolok ukur penilaian tentang keadilan sosial. Kemampuan ini membantu seseorang untuk merefleksikan tujuan dan harapan dalam hidupnya. ${ }^{44}$ Manusia paripurna adalah manusia bebas yang menjalani hidup bermartabat, dapat bekerja sama dengan orang lain, dan aktif. Sebagai makhluk yang berakal budi, mereka diharapkan menggunakan nalar dan kemampuannya untuk hidup bersosialisasi dan bekerja sama timbal balik $^{45}$. Dia membuat daftar sepuluh (10) kategori kemampuan fungsional yang utama, yaitu: hidup, kesehatan tubuh, integritas tubuh, indera-imajinasipikiran, emosi, nalar praktis, afiliasi, spesies lain, bermain, dan kendali atas

41 Nussbaum, Not For Profit, 68.

42 Nussbaum, Cultivating Humanity, 30-1.

43 Martha Craven Nussbaum, Creating Capabilities: The Human Development Approach. (Cambridge, Ma.: The Belknap Press of Harvard University Press, 2011), 9.

44 Ibid, 20.

45 Martha Craven Nussbaum, Women And Human Development: The Capabilities Approach. (New York: Cambridge University Press, 2000), 72. 
lingkungan. ${ }^{46}$ Daftar kategori kemampuannya menyangkut elemen-elemen penting dalam mengukur kualitas hidup seseorang yang beragam dan berbeda secara kualitatif. Kesehatan, integritas tubuh, pendidikan, dan aspek-aspek lain dalam hidup setiap orang tidak bisa digantikan atau dikurangi menurut skala angka tunggal. ${ }^{47}$

Berbicara tentang kemampuan tidak terlepas dari pendidikan, terutama untuk perempuan di negara berkembang. Dalam penelitian Nussbaum, kurang dari $50 \%$ perempuan di sana bisa membaca dan menulis. Selain itu, terdapat jurang perbedaan gender yang lebar dan tidak selalu disebabkan ekonomi karena dapat diatasi dengan perencanaan publik yang bijaksana. Universitas negeri kurang merekrut perempuan dari latar belakang pedesaan yang kekurangan dan kurang memberi pelatihan yang dibutuhkan mereka. Selain itu, pelatihan yang ditawarkan kurang mempersiapkan perempuan untuk menjadi pemimpin. Dan menjadi tidak mengherankan ketika perempuan yang terpelajar adalah hasil didikan dari luar negeri. Hal yang menggembirakan adalah adanya usaha untuk mengembangkan pendidikan untuk perempuan. Kamal Ahmad, seorang pengacara dari Bangladesh, dianggap sebagai orang yang peduli pada kaum perempuan karena mendirikan universitas baru untuk mereka. Universitas ini diberi nama: Asian UniversityforWomen (AUW), yang ditujukan untuk perempuan di Asia, terutama di daerah pedesaan yang miskin. Sumber utama dari pendidikan ini adalah mengembangkan ide Tagore yang berfokus pada melatih imajinasi melalui seni. Hal ini dilakukan untuk membebaskan perempuan dari belenggu tradisi yang banyak membatasi gerak mereka. Universitas ini berkomitmen untuk menghasilkan warga dunia terutama perempuan - yang banyak akal dan bersikap kritis, warga negara yang dibutuhkan oleh semua negara untuk memecahkan masalah global. Kurikulum dibuat dengan tujuan menghasilkan perempuan muda yang cerdas untuk diri mereka sendiri, kemudian ikut berpartisipasi dalam memecahkan masalah global, memiliki rasa percaya diri untuk mengungkapkan ide-idenya, dan untuk menghargai dan memahami orang-orang dengan pemikiran yang berbeda. Para perempuan ini dibekali pengetahuan tentang sejarah dunia, agama-agama di dunia, debat etis seputar globalisasi dan masalah mendesak lainnya. Mereka diharapkan menjadi peserta yang cerdas dalam debat etis, dengan kesadaran yang kuat tentang masalah etika. Pengembangan imajinasi adalah kunci utama dalam kurikulum pendidikan yang berpusat pada perempuan. Para perempuan ini diharapkan mampu mengekspresikan diri mereka melalui seni dan berpikir kreatif tentang kesulitan orang yang dekat dan jauh. Pendidikan pada universitas mengajak mereka mengembangkan kemampuan nalar kritis dan aktif berpartisipasi dalam debat dan dialog terbuka. ${ }^{48}$

46 Nussbaum, Creating Capabilities: 33-4.

47 Ibid, 18.

48 Nussbaum, "Liberal \& Global Community", 45-6. 
Pemberdayaan perempuan ini, menurut Nussbuam, menjadi tolok ukur penilaian apakah kemampuan sudah terpenuhi atau belum. Indikasi kemampuan perempuan dinilai melalui pendidikan. Sebab, pendidikan menjadi pembuka jalan bagi perempuan untuk dapat melakukan kontrol terhadap lingkungan, ikut berpartisipasi dalam politik, mengetahui dan memahami hak dan kewajibannya saat bekerja di luar rumah (termasuk juga kepemilikan harta), bebas menjadi dirinya sendiri dan mendapat perlindungan saat melakukan aktivitas di luar. Dalam hal kesehatan reproduksi, perempuan yang paham dan mengenal dirinya dengan baik dapat membuat keputusan tepat untuk tubuhnya. Untuk segi emosional, pemerintah tidak mungkin menjamin secara mutlak kesehatan dari segi ini - khususnya perempuan akan tetapi dapat membuat kebijakan yang diatur dalam hukum yang memberi dampak penting bagi segi emosional. Pemerintah dapat menyediakan payung hukum untuk mengatur kehidupan domestik keluarga (kekerasan), hukum tentang pemerkosaan, dan tentang keamanan publik. Sedangkan kemampuan berpikir etis dan afiliasi dapat diterapkan di dunia kerja dan kegiatan organisasi dalam masyarakat. Setiap orang - termasuk perempuan - berhak mengeluarkan pendapat dan terlibat aktif dalam kegiatan bermasyarakat dan dalam lingkungan kerjanya. ${ }^{49}$

Kemampuan yang hendak diuraikannya berpusat pada penilaian tentang kualitas hidup dan teori tentang keadilan sosial dasar. Ketika Sen menegaskan bahwa manusia merupakan tujuan dan bukan alat, menjadi jelas bahwa setiap orang memiliki kesempatan untuk bebas memilih. Kemampuan dalam pandangan Nussbaum merupakan kesempatan yang dimiliki setiap orang untuk bebas menjadi dirinya dan melakukan apa yang menjadi pilihannya. Masyarakat hendaknya mendukung agar setiap orang memiliki kebebasan untuk bertindak berdasarkan pilihannya. Dia membagi kemampuan menjadi tiga (3): kemampuan internal (internal capabilities), kemampuan internal yang dikembangkan (developed internal capabilities), dan kemampuan gabungan (combinedcapabilities). Kemampuan dasar (basiccapabilities) adalah kemampuan bawaan pada diri setiap orang yang hendaknya dilatih dan dikembangkan, sebab kemampuan ini berperan penting dalam pendekatan perkembangan manusia atau perealisasian diri. Baginya, pengembangan kemampuan bawaan tidak berasal dari DNA; nutrisi ibu dan masa kehamilan memainkan peran penting dalam pembentukan bayi. Setelah anak lahir, orang tuanya dan kondisi lingkungan ikut berperan dalam perkembangan awal dan pembentukan kemampuan bawaannya. Kemampuan internal ini kemudian digabungkan dengan hak politik dan sosialnya dan ini hendaknya proposisional dengan kecerdasan atau keterampilannya. Anak berkebutuhan khusus (a childwithDownsyndrome) akan dihargai martabatnya bila mereka diperlakukan dengan mengembangkan kekuatan pikirannya melalui

49 Nussbaum, Women And Human Development: 81-2. 
pendidikan yang sesuai. Bentuk lain dari kemampuan adalah berfungsinya (functioning) seseorang untuk aktif mewujudkan akan satu atau lebih dari daftar kemampuan tersebut. Berfungsinya ini membuat seseorang dapat memiliki kemampuan untuk menikmati kesehatan yang baik atau untuk bersantai menikmati keindahan alam. Saat manusia berfungsi, dia memiliki kesempatan dan kebebasan untuk menjadi dan melakukan tindakan yang merupakan hasil atau perwujudan dari kemampuannya. ${ }^{50}$

Perempuan cenderung dilihat tergantung, pasif, harus dilindungi, dan bukan sebagai manusia mandiri yang hendaknya dihargai haknya untuk memilih. Nussbaum kemudian menegaskan kemampuan dalam pandangannya adalah kebebasan untuk meraih perpaduan berfungsinya sebagai manusia. Kemampuan di sini bukan semata yang berada di dalam diri seseorang, tetapi merupakan kesempatan atau kebebasan yang dibuat berdasarkan perpaduan (combinations) dari kemampuan personal dan politik, sosial, dan lingkungan ekonomi. Dan menjadi jelas bahwa perpaduan kemampuan adalah kesempatannya untuk memilih dan bertindak dalam situasi politik, sosial, dan ekonomi yang khusus. ${ }^{51}$ Yang harus diperhatikan adalah perpaduan kemampuan sering dipahami sebagai kemampuan internal ditambah dengan kondisi sosial, politik, ekonomi yang bisa dipilih untuk berfungsinya, tetapi pada kenyataannya komunitas hanya membuat perpaduan kemampuan dan melupakan kemampuan internal..$^{52}$

\section{Kesimpulan}

Pendidikan bagi Nussbaum adalah untuk semua orang dari segala lapisan dan golongan. Dia berfokus pada pendidikan humaniora yang memadukan pengujian diri kritis Sokrates dan imajinasi melalui seni dan sastra untuk menumbuhkan simpati. Pendidikan bertujuan membentuk masyarakat demokratis yang adil dan sejahtera. Demokrasi sangat penting dan dibutuhkan dalam hidup bermasyarakat pada suatu negara. Masyarakat demokratis yang dicita-citakannya ditandai dengan adanya kesetaraan, keadilan dan kesejahteraan bagi semua orang di segala lapisan dan golongan. Pendidikan berperan penting untuk mengubah hidup seseorang.

Imajinasi memiliki peran yang tak kalah penting dalam pendidikan, yang menurutnya mulai diabaikan atau mungkin dihilangkan dalam kurikulum. Pendidikan saat ini cenderung berpusat pada kemajuan ilmu pengetahuan teknis untuk mendongkrak pertumbuhan ekonomi. Dan hal ini mengabaikan hak untuk bertumbuhnya karakter anak-anak. Pelajaran di sekolah yang didapat anak-anak, kecenderungan untuk menghafal, telah memberangus

50 Nussbaum, Creating Capabilities: 18-26.

51 Nussbaum, Not For Profit, 20.

52 Ibid, 22. 
hak asasi anak untuk mengembangkan imajinasi dan pikiran kritisnya. Mereka seolah digiring untuk menjadi patuh dan pasif, kurang mendapat kesempatan untuk bebas berpendapat dan menjadi diri sendiri. Dia tidak menentang ilmu pengetahuan dan teknologi, bahkan menganjurkan agar setiap negara terus berinovasi. Namun pendidikan humaniora tetap dibutuhkan untuk pengembangan karakter moral. Pendidikan sejati dapat memadukan pengetahuan, teknologi, dengan pendidikan humaniora yang mengembangkan imajinasi melalui seni. Sebab, imajinasi dapat menumbuhkan empati yang melahirkan kepekaan dan kepedulian pada sesama.

Dunia global juga menjadi perhatiannya, mengingat saat ini tidak ada satu negara yang homogen. Keragaman adalah kemutlakan dalam hidup bernegara. Pendidikan humanioranya menawarkan pandangan yang menerima segi multikultural karena pada dasarnya setiap orang adalah bagian dari warga dunia yang disebut kosmopolitan. Kurikulum pendidikan perlu diubah agar dapat mengikuti perkembangan dunia. Perlu memasukkan pelajaran tentang sejarah, budaya, politik, dan agama agar setiap orang terbuka pada perbedaan di sekitarnya. Demokrasi adalah menerima dan menghargai perbedaan serta bekerja sama lintas negara untuk memecahkan masalah global seperti kelaparan, kerusakan lingkungan hidup, perubahan iklim, dan yang lainnya. Pendidikan menjadi garda depan untuk perubahan yang lebih baik. Menurut pendapatnya, pendidikan adalah proses seseorang untuk dapat memahami sesuatu, bukan rutinitas semata, dan juga meningkatkan kemampuannya. ${ }^{53}$

Kemampuan dalam pandangannya adalah kesempatan atau kebebasan seseorang untuk memilih menjadi dan melakukan apa yang ingin dilakukannya. Kemampuannya ini merupakan indikator penilaian tentang kualitas hidup seseorang dan teori keadilan sosial dasar. Perempuan menjadi pusat perhatiannya, sebab cenderung dianggap pasif dan kekanak-kanakan. Kemampuan menjadi tolok ukur yang membantu perempuan untuk keluar dari prasangka yang berkembang dan memiliki kesempatan serta kebebasan untuk memilih tindakannya sendiri. Dan kemampuan ini dapat diwujudkan saat seseorang terdidik untuk bersikap kritis dan imajinatif. Imajinasi sangat penting untuk dipelihara perkembangannya.

Pemikiran Nussbaum yang menyatakan bahwa pengembangan kemanusiaan dan pendidikan warga negara dunia yang terpinggirkan merupakan bahaya, ${ }^{54}$ tidak dapat disangkal kebenarannya. Pemikirannya tentang pendidikan humaniora tetap dibutuhkan untuk mengembangkan kesetaraan dalam masyarakat demokratis yang dapat menerima keragaman, ${ }^{55}$ adalah sangat tepat. Namun, tidak dapat dipungkiri bahwa kemajuan

53 Nussbaum, Not For Profit, 63.

54 Nussbaum, Not For Profit, 7.

55 Nussbaum, Cultivating Humanity, 14-9. 
teknologi yang berkembang semakin pesat merupakan hal mutlak yang harus kita terima. Di samping itu tidak mungkin untuk menutup mata bahwa kemajuan suatu bangsa tetap membutuhkan perputaran roda ekonomi. Sejatinya, pendidikan yang merawat kemanusiaan tetap membutuhkan pendidikan kejuruan (vocation) untuk melatih ketrampilan seseorang. Ketrampilan ini menjadi bekal untuk seseorang berjuang dan bertahan dalam pergulatan hidupnya sehari-hari. ${ }^{56}$ Selain itu, pendidikan humaniora adalah pendidikan yang luzves karena mampu menjalin kerja sama dengan bidang ilmu yang lain. Pendidikan humaniora yang menekankan nalar kritis membuat seseorang memiliki kepribadian adaptif yang siap untuk menerima perubahan. Di tengah perdebatan antara ilmu-ilmu humaniora dan teknis, pendidikan humaniora masih memegang teguh pesan Seneca untuk menjadi aspek pendidikan yang membebaskan manusia. Pendekatan interdispliner menjadi bagian penting dalam proses belajar mengajarnya, terutama yang berfokus pada diskusi dan penyelidikan kritis. ${ }^{57}$ Pemikiran NelNoddings dengan tepat menggambarkan keuntungan dari penggabungan pendidikan humaniora dan ketrampilan. Menurutnya, pendidikan sejatinya membantu setiap orang untuk mengetahui dasar-dasar ilmu pengetahuan dan kehidupan sosial, serta landasan hidup yang ingin diraihnya. Untuk itu pendidikan ketrampilan yang diseimbangkan dengan pendidikan humaniora membantu setiap orang untuk merefleksikan hidup agar lebih bermakna. Dia menambahkan bahwa ada tiga wilayah utama dalam hidup yang hendaknya menjadi perhatian setiap orang: pekerjaan, kehidupan pribadi dan keluarga, dan partisipasi dalam hidup bermasyarakat. Pada saat setiap orang dilatih untuk memiliki ketrampilan dan mengembangkan kemampuan tersebut agar semakin dapat menguasainya dengan baik, keahlian tersebut dapat menjadi bekal mereka untuk bertahan hidup. ${ }^{58}$ Pendidikan dapat mengubah hidup seseorang, seperti yang diharapkan Nussbaum, bila dapat menggabungkan pendidikan humaniora dan ketrampilan. Gabungan dari dua pendidikan ini dapat menjadi bekal seseorang mencari pekerjaan sebagai upaya untuk memenuhi kebutuhan hidupnya.

Nussbaum sangat mendukung perkembangan teknologi, bahkan mendorong suatu negara untuk terus berinovasi. Namun sangat disayangkan

56 Martin Gunderson, "Book Reviews: Martha C. Nussbaum. Cultivating Humanity: A Classical Defense of Reform in Liberal Education", Frontiers Journal, Vol. 9. (Konten ini diunduh dari: https://frontiersjournal.org/wp-content/uploads/2015/09/GUNDERSON-frontiersXIBookReview.pdf , 2015), 247

57 James P., Rice, "What Should We be Teaching? Nussbaum, Seneca, and the Liberal Arts", Modern Language Studies, Vol. 36. No. 1. (Konten ini diunduh dari: http://www.jstor.org/ stable/27647881,2006), 52.

58 Noddings, Nel, "Renewing The Spirit Of The Liberal Arts", dalam The Journalof General Education. Vol. 62, No. 2-3. (Konten ini diunduh dari: https://www.jstor.org/stable/10.5325/ jgeneeduc.62.23.0077, 2013), 81-3. 
bahwa dia kurang tertarik pada penggunaan teknologi. Dia mengakui bahwa penggunaan teknologi memiliki efek yang kurang baik dalam hidup berdemokrasi. Internet dan media sosial cenderung menjadikan seseorang memiliki pikiran yang dangkal karena kecepatan untuk segera membuat komentar, mengubah orang menjadi narsistik karena ingin selalu tampil dalam media sosial, dan "keberadaan" seseorang cenderung dinilai dari tombol suka (like) atau tidak suka (dislike). ${ }^{59} \mathrm{Di}$ samping itu, dia berpendapat bahwa internet cenderung mengganggu karena mengeksploitasi tubuh perempuan. ${ }^{60}$

Pandangan Nussbaum ini dapat diatasi dengan pendidikan dan pendampingan dari orang tua. Sebab perubahan adalah hal yang mutlak dalam hidup. Perkembangan teknologi, bila dimanfaatkan dengan baik, dapat dimanfaatkan untuk menyebarkan hal-hal positif dalam hidup. Pendidikan pada saat ini sedang mengalami gejolak yang luar biasa, terutama dalam menghadapi wabah Covid-19, ketika kegiatan belajar mengajar tidak dapat dilakukan secara tatap muka tetapi secara daring. Tulisan ini hendak menawarkan imajinasi yang menggerakkan dengan cara membangun kepercayaan diri pada anak-anak melalui nilai-nilai positif. Nilai-nilai positif ini membuat anak-anak tergerak hatinya untuk berani melakukan perubahan dan menumbuhkan rasa percaya diri, yang dapat membuat seseorang memiliki kemampuan untuk meraih cita-citanya, dan menumbuhkan keyakinan bahwa dirinya adalah manusia yang berkualitas. Imajinasi yang menggerakkan ini akan semakin berdaya guna dan memiliki kekuatan dengan memanfaatkan teknologi yang menjadi sarana efektif untuk menyebarkan nilai-nilai kemanusiaan. ${ }^{61}$ Kemajuan teknologi adalah suatu keniscayaan yang akan lebih baik bila dimanfaatkan untuk mengembangkan pendidikan humaniora.

59 Pendapat Nussbaum ini dapat dilihat pada Interview with Professor Martha Nussbaum - Part 4 di $h t t p s: / / y o u t u . b e / B G N K c Y J d u J g$, pada menit ke 01.07-03.50, diunduh pada Minggu 4 Oktober. 2020, jam 21.30.

60 Saul Levmore and Martha Nussbaum, ed., The Offensive Internet: Speech, Privacy, and Reputation, (Cambridge: Hardvard University Press, 2010.), 68-75.

61 University of Maryland-Baltimore County (UMBC) adalah universitas yang menjadi teladan dalam mengembangkan nilai-nilai kemanusiaan dengan memanfaatkan teknologi. Pimpinan dan para pendidik di sana menyadari bahwa pendidik di masa depan hendaknya memiliki kemampuan untuk bekerja sama dengan manusia lain dan teknologi. Sebab, pada saat ini kita memasuki zaman di mana manusia berhadapan dengan teknologi. Pemanfaatan teknologi dilakukan dengan cara mendorong mahasiswa di jurusan pendidikan untuk membuat rencana pengajaran dalam ilmu-ilmu sosial yang memanfaatkan teknologi ketika mengajar. Teknologi menjadi sarana yang dimanfaatkan untuk menyebarkan nilai-nilai kemanusiaan. Dan UMBC menjadi bukti bahwa ilmu-ilmu untuk merawat kemanusiaan dapat dipadukan dengan bidang teknologi. Hrabowski, Freman A. III. Lee, Diane M. \& Martello, John S., "Educating Teachers for the 21st Century: Lesson Learned", The Journal of Negro Education, Vol. 68, No. 3 (Konten ini diunduh dari https:// www.jstor.org/stable/2668102, 1999), 297. 


\section{Kepustakaan}

Levmore, Saul and Nussbaum, Martha C. ed. The Offensive Internet: Speech, Privacy, and Reputation. Cambridge: Hardvard University Press, 2010.

Nussbaum, Martha Craven. The Poetic Justice: The Literary Imagination and Public Life. Boston: Beacon Press, 1995.

. Cultivating Humanity: A Classical Defense of Reform In Liberal Education. Cambridge: Harvard UniversityPress, 1997.

. Women And Human Development: The Capabilities Approach, New York: Cambridge University Press, 2000.

. Diambil dalam Siegel, Harvey. Ed. The Oxford Handbook of Philosophy of Education. Oxford: Oxford University Press, 2009.

. Not For Profit: Why Democracy Needs The Humanities. Princeton: Princeton University Press, 2010.

. Creating Capabilities: The Human Development Approach. Cambridge,

Ma.: The Belknap Pressof Harvard University Press, 2011.

Sudiarja, A. ed. Karya Lengkap Driyarkara: Esai-Esai Filsafat Pemikir yang Terlibat Penuh Dalam Perjuangan Bangsanya. Jakarta: Gramedia Pustaka Utama, 2006.

\section{Sumber Lain}

Cook-Sather, Alison. "Students as Learners and Teachers: Taking Responsibility, Transforming Education, and Redifining Accoutability". Dalam Curriculum Inquiry. Vol. 40 - No. 4, 2010. Konten ini diunduh dari http:/ /wwww.jstor.org/stable/40962986 pada Sabtu, 11 Apr 2019, 14:51:36.

Friedman, Marilyn. "Educating for World Citizenship". Dalam Ethics. Vol. 110 - No 3, 2000. Konten ini diunduh dari https://www.jstor.org/stable/ 10.1086/233325 pada Kamis, 11 Apr 2019, 14:38:50.

Gunderson, Martin. "Book Reviews: Martha C. Nussbaum. Cultivating Humanity: A Classical Defense of Reform in Liberal Education". Dalam Frontiers Journal, Vol. 9, 2015. Konten ini diunduh dari https://frontiersjournal.org/ wp-content/uploads/2015/09/GUNDERSON-frontiersXI-BookReview.pdf pada Selasa, 11 Juni 2019, 11:47:45.

Hrabowski, Freman A. III. Lee, Diane M. \& Martello, John S. “Educating Teachers for the $21^{\text {st }}$ Century: Lesson Learned", dalam The Journalof Negro Education, Vol. 68, No. 3, 1999. Konten ini diunduh dari https://wwww.jstor.org/ stable/2668102, pada Rabu 5 Agustus 2020, 22:48:05.

Naseem, M. Ayas and Hyslop-Margison, Emery J. “Nussbaum's Concept of Cosmopolitanism: Practical Possibility or Academic Delusion?". Dalam Paideusis. Vol. 15 - No. 2, 2006. Konten ini diunduh dari https:// journals.sfu.ca/pie/index.php/pie/article/view/75/25Eved=2ahUKEwi9m pada Kamis, 11 Apr. 2019, 15:25:01. 
Noddings, Nel. "Renewing The Spirit Of The Liberal Arts", dalam The Journal of General Education. Vol. 62, No. 2-3, 2013. Konten ini diunduh dari https:/ /wwww.jstor.org/stable/10.5325/jgeneeduc.62.23.0077, pada Senin 11 November 2019, 20:01.

Nussbaum, Martha Craven. "Compassion: The Basic Social Emotion", dalam Social Philosophy and Polici Foundation, Vol. 13 - Issue 1, 1996. Konten ini diunduh dari https://people.whitman.edu/ frierspr/nussbaum\% 25201996\% 2520compassion.pdfEved =2ahUKEwiaz-7Cq6zuAhXNXisKHV99Ck EQFjADegQIBBABE $\mathrm{susg}=A O v$ Vaw1XFcA40U-AH-qVSqkGoKXqEcshid= 1611208591114 pada Kamis, 11 Apr. 2019, 15:23:03.

. "Humanities and Human Development", dalam The Journal of Aesthetic Education, Vol. 36, No. 3, 2002. Konten ini diunduh dari http:// wwww.jstor.org/stable/3333596 pada Kamis, 11 Apr. 2019, 14:42:54.

. "Liberal \& Global Community", Liberal EducationVol 90 - No.1, 2004. Konten ini diunduh dari https://files.eric.ed.gov/fulltext/EJ728534.pdfE्Eved= 2ahUKEwjFyt2krKzuAhX863MBHWj8DZEQFjACegQIChACEusg=AOv Vaw3zK1SspzZffLLPd4iPTVM5 pada Kamis, 11 Apr. 2019, 15:20:02.

Rice, James P. "What Should We be Teaching? Nussbaum, Seneca, and the Liberal Arts", dalam Modern Language Studies, Vol. 36. No. 1, 2006.. Konten ini diunduh dari http://wwww.jstor.org/stable/27647881 pada Rabu 5 Agustus 2020, 22:38:05.

Roth, Jeffrey. "Can The Balm of Stoicism Salve the Wound of Multiculturalism? A Reviewof Martha C. Nussbaum. "Cultivating Humanity: A Classical Defense of Reform in Liberal Education". Dalam Journal of Thought. Vol. 35 No. 1, 2000. Konten ini diunduh dari http://wwww.jstor.org/stable/42589600 pada Kamis, 11 Apr. 2019, 14:42:47.

\section{Sumber Internet}

Interview with Professor Martha Nussbaum - Part 4 di https://youtu.be/BGN KcYJduJg, pada menit ke 01.07-03.50, diunduh pada Minggu 4 Oktober. 2020, jam 21.30 